ROBERT J.GORDON

Northwestern University

\title{
Understanding Inflation in the 1980s
}

ThE association between the inflation rate and the level of aggregate demand, and the related concept of the natural unemployment rate, have been perennial Brookings Panel topics. This fifteenth anniversary of the Panel seems an appropriate occasion to take another look at the U.S. inflation process. After a series of inflationary "surprises" during the 1970 s, when the inflation rate was regularly underpredicted by forecasters and inflation analysts, inflation has decelerated faster and further since 1980 than many thought possible. Does the disinflation of the early 1980s call for a new approach to the study of the inflation process, as did the stagflation of 1969-71 and the supply shocks of 1973-74? Or has the research effort of the 1970s yielded a quantitative representation of the inflation process and the natural rate of unemployment that remains relatively intact in the mid-1980s?

At the tenth anniversary meeting of the Brookings Panel, James Tobin lamented the constantly worsening views of the inflation-unemployment trade-off and the natural unemployment rate presented in papers over the first decade of the Panel: "One regularity of Brookings panel meetings and papers has been the relentless rise in numerical estimates of the fullemployment rate of unemployment. . . . From 3 percent in the early 1950s, these explicit or implicit estimates of the natural rate seem to have risen successively to 4 percent in the 1960s, 5 percent in the early 1970 s, then 6 percent. In the early 1980s, it is easy to predict, the magic number will not be lower than 7 percent."

This research is supported by the National Science Foundation. I am grateful to Nathan Balke for creating the data and carrying out the econometric estimation with great speed and efficiency, and to Joan Robinson, who has done her usual splendid and indispensable job in typing the paper.

1. James Tobin, "Stabilization Policy Ten Years After," BPEA, 1:1980, p. 58. 
Has the tide finally turned? Does the disinflation of the 1980s imply that the natural unemployment rate has remained steady at 6 percent rather than creeping up to 7 percent, or, better yet, that the naiural rate has begun to recede toward 5 percent? Is an inflation equation specified in 1980 able to track the 1981-84 disinflation in dynamic simulations, and do its coefficients remain unchanged when the sample period is extended to the end of 1984 ?

This paper is a sequel to two of my earlier BPEA papers. Like my 1977 retrospective, it attempts to identify elements of continuity and change in the inflation data within the context of my earlier research, and it contains no review of the literature. ${ }^{2}$ It also follows up my 1984 paper, which created a measure of potential GNP that corresponds to a series for the natural rate of unemployment developed in my earlier research. ${ }^{3}$ (Hereafter I refer to potential GNP as natural GNP to emphasize its correspondence with the natural unemployment rate.) In the series the natural unemployment rate starts at about 5 percent in the 1950 s, and rises in response to demographic changes to about 6 percent beginning in the early 1970s. Rather than start from scratch with another investigation of alternative unemployment concepts, this paper takes as its basic measure of aggregate demand pressure the ratio of actual real GNP to the natural GNP series developed in 1984. A major purpose here is to determine whether the natural GNP series understates or overstates the economy's noninflationary operating level.

The Phillips curve hypothesis, that wages adjust gradually rather than instantaneously in the face of an excess demand for or supply of labor, figures prominently in any model of the inflation process. Rather than postulate a wage equation of the general Phillips curve form, however, this paper specifies labor demand and supply functions and then derives a wage equation based on an explicit assumption about partial adjustment. The advantage of this approach is that it provides for the inclusion of numerous terms in the wage equation in addition to excess labor

2. Robert J. Gordon, "Can the Inflation of the 1970s Be Explained?" BPEA, 1:1977, pp. 253-77.

3. See Robert J. Gordon, "Unemployment and Potential Output in the 1980s, ' BPEA, 2:1984, pp. 737-64. My earlier research estimated a constant natural rate for George Perry's weighted unemployment concept and calculated the aggregate unweighted unemployment rate corresponding to that constant weighted rate. See Robert J. Gordon, "Inflation, Flexible Exchange Rates, and the Natural Rate of Unemployment," in Martin N. Baily, ed., Workers, Jobs, and Inflation (Brookings, 1982), pp. 88-152. 
demand or supply, including changes in tax rates and changes in the consumer price index (CPI) relative to the product price index. When the wage equation is combined with a price equation of the "markup" type, a reduced-form equation for the inflation rate can be derived to relate inflation to lagged inflation, excess demand, tax changes, and various "cost-push" or "supply-shock" terms. The reduced-form equation can then be used to define the natural rate of unemployment, and to relate this concept back to the terms in the original labor demand and supply equations. This reduced-form equation is similar to those that I developed and began to estimate in 1980 , but it contains several additional variables that, at least in theory, should be relevant. ${ }^{4}$

The paper concentrates on reduced-form equations with both the original 1980 and augmented specifications and reports on their stability and performance in dynarnic simulations. A historical decomposition shows the contribution of particular variables to the acceleration of inflation between 1964 and 1971, and 1971 and 1980, as well as to the deceleration during the early 1980s. The estimates of the reduced-form inflation equation are used to address several issues that have important implications for the choice among alternative policies:

-Can aggregate demand policy stimulate sufficient real GNP growth to reduce the unemployment rate to 6 percent without causing a reacceleration of inflation, or is the "safe" unemployment target closer to 7 percent? What would be an appropriate path for nominal GNP growth to arrive with a "soft landing" at a 6 percent unemployment rate?

-What has been the contribution of the appreciating dollar and declining relative import prices to the 1981-84 disinflation? How much would inflation reaccelerate if the dollar were to return over the next four years to its 1980 level?

-What, in retrospect, was the economy's output "sacrifice ratio" (cumulative lost output per percentage point reduction of inflation) during the disinflation of 1981-84? How much was the sacrifice ratio

4. The basic format of the reduced-form equation was developed and tested on annual data in Robert J. Gordon, "A Consistent Characterization of a Near-Century of Price Behavior," American Economic Review, vol. 70 (May 1980, Papers and Proceedings, 1979), pp. 243-49. It was applied to quarterly data in Gordon, "Flexible Exchange Rates." The same specification, with a few minor changes, was estimated and simulated in Robert J. Gordon and Stephen R. King, "The Output Cost of Disinflation in Traditional and Vector Autoregressive Models," BPEA, 1:1982, pp. 205-42. 
reduced by the decline in the relative prices of food, energy, and nonfood, nonfuel imports?

-Did personal tax reductions make any special contribution to the disinflation of the early 1980s?

-What, if anything, did the federal government do during the 1970 s to cause inflation, leaving aside its effect on the level of aggregate demand? Were there "self-inflicted wounds" that can be identified and, possibly, avoided in the future?

-Is there any special role for the money supply in the U.S. inflation process? Is it sufficient for the monetary authorities to target nominal GNP in order to control inflation, or must they give additional weight to the meney supply when its growth diverges from that of nominal GNP?

\section{Specification of Wage and Price Equations}

The Phillips curve approach to wage and price adjustment postulates that wages and prices adjust gradually to a disequilibrium in labor and product markets. The original naive 1960s Phillips curve predicted a negative correlation between inflation and unemployment, and was undermined by the positive correlation between the two that emerged in the 1970s. Indeed, Robert E. Lucas, Jr., and Thomas J. Sargent, in a famous polemic, argued that it was on the predictive failure of the earlier Phillips curve that the empirical foundations of Keynesian macroeconomics had crumbled, and that a new macroeconomics would have to build on the site of the "wreckage." 5

To make the naive Phillips curve of the 1960s perform adequately in empirical tests, it is necessary to add two crucial elements. The first is long-run neutrality, embodying the property that a permanent acceleration of nominal GNP growth induces only a temporary expansion of output. I have dubbed this the NRH-GAP ("natural rate hypothesis plus gradual adjustment of prices") approach. ${ }^{6}$ The second element is an allowance for shifts in the short-run aggregate supply function in response

5. Robert E. Lucas, Jr., and Thomas J. Sargent, "After Keynesian Macroeconomics," in Federal Reserve Bank of Boston, After the Phillips Curve: Persistence of High Inflation and High Unemployment, Conference Series 19 (FRBB, 1978), pp. 49-72.

6. Robert J. Gordon, "Price Inertia and Policy Ineffectiveness in the United States, 1890-1980,' Journal of Political Economy, vol. 90 (December 1982), pp. 1087-1117. 
to changing raw materials prices, taxes, and other factors. Elsewhere I have referred to this approach as the "triangle" model of inflation, where the three sides of the triangle are gradual adjustment, demand, and supply. Here it may be more helpful to label it the "augmented Phillips curve."

\section{A DYNAMIC MODEL OF WAGE AND PRICE ADJUSTMENT}

I begin, however, not with the augmented Phillips curve, but with an explicit model of labor supply and demand in which the wage rate adjusts in response to any change in the size of the gap between the two. The advantage is that the influence of supply shocks, the productivity slowdown, and tax changes on wage and price behavior can be motivated concretely in the model. The model also allows a definition of relationships between the much-discussed and related concepts of real and nominal wage stickiness, the Keynesian output gap, and the natural rate of unemployment.

The first step is to write a production function in which output, $Q_{t}$, is written as a function of labor input, $N_{t}$, and a multiplicative factor, $\theta_{t}$, that incorporates the effects of capital and materials inputs and of technological change:

$$
Q_{t}=\theta_{t} Q\left(N_{t}\right), Q^{\prime}>0 .
$$

The real product wage, which is set equal to the marginal product of labor, is expressed as the ratio of the actual nominal wage, $W_{t}$, to the expected product price, $P_{t}^{e}$, adjusted for the influence of indirect taxes and payroll taxes paid by employers, $T_{t}^{E}:{ }^{7}$

$$
\frac{W_{t} T_{t}^{E}}{P_{t}^{e}}=\theta_{t} Q^{\prime}\left(N_{t}\right) .
$$

7. The expression $T^{E}$ represents the product of an indirect tax factor and a payroll tax factor as follows:

$$
\begin{aligned}
T^{I} & =\left(\frac{1}{1-\tau^{I}}\right) \\
T^{S} & =\left(\frac{1}{1-\tau^{S}}\right) \\
T^{E} & =T^{I} \cdot T^{\mathcal{S}},
\end{aligned}
$$

where $\tau^{I}$ is the indirect tax rate and $\tau^{S}$ is the payroll tax rate. 
Equation 2, inverted, expresses the demand for labor as a function of the real expected product wage, adjusted for the tax term, $T_{t}^{E}$, and the productivity shift factor, $\theta_{t}$ :

$$
N_{t}^{d}=N^{d}\left(\frac{W_{t} T_{t}^{E}}{\theta_{t} P_{t}^{e}}\right), N^{\prime d}<0 .
$$

The supply of labor is a positively sloped function of the real wage stated in terms of the expected consumer price index, $C_{t}^{e}$, with an adjustment for a personal tax factor, $T_{t}^{p}: 8$

$$
N_{t}^{s}=N^{s}\left(\frac{W_{t}}{\Lambda_{t} T_{t}^{P} C_{t}^{e}}\right), N^{\prime s}>0 .
$$

In equation 4 the factor $\Lambda_{t}$ is the "aspiration" real wage that workers compare with the tax-adjusted real expected wages.

The excess demand for labor, $X_{t}$, can be expressed as the difference between the logs of labor demand and supply:

$$
X_{t}=\ln \left(N_{t}^{d}\right)-\ln \left(N_{t}^{s}\right) .
$$

This expression can be converted inte a relationship between the proportional rates of growth of the demand for and supply of labor by substituting equations 3 and 4 into equation 5, taking time derivatives, and rearranging:

$$
x_{t}=-(a+b)\left(w-x-p^{e}\right)_{t}+b\left(\lambda-\theta+c^{e}-p^{e}+t^{P}\right)_{t}-a t_{t}^{E} .
$$

Here lowercase letters indicate rates of change $(w=d W / W)$, and $a$ and $b$ are, respectively, the real-wage elasticities of labor demand and supply.

The Phillips curve adjustment hypothesis is that the nominal wage rate moves in the direction needed to eliminate the excess demand for labor at a rate that depends on the size of the gap between demand and supply:

$$
x_{t}=-g X_{t},
$$

8. In parallel with the other taxes, the personal tax factor rather than the personal tax rate is entered into the equation, where

$$
T_{t}^{P}=\frac{1}{1-\tau_{t}^{P}},
$$

and $\tau_{t}^{p}$ is the personal income tax rate. 
where once again lowercase letters throughout represent proportional rates of change. When the right-hand sides of equations 6 and 7 are set equal to each other and solved for the rate of change of real unit labor cost, the result is the augmented Phillips curve wage change equation:

$$
w_{t}-\theta_{t}-p_{t}^{e}=\frac{1}{a+b}\left[b\left(\lambda-\theta+c^{e}-p^{e}+t^{p}\right)_{t}-a t_{t}^{E}+g X_{t}\right] .
$$

\section{INFLATION EQUATIONS}

Equation 8 can be combined with a markup price equation to yield a reduced-form equation for inflation. We assume that the product price is set as a weighted average of domestic unit labor cost adjusted for a payroll tax factor, $T_{t}^{S}$ (defined in footnote 7 ), and the domestic currency value of the foreign product price, $F_{t}$, with a variable markup, $M$, that depends on excess demand, $V_{t}$, in the commodity market:

$$
P_{t}=T_{t}^{l} M\left(V_{t}\right)\left(T_{t}^{S} W_{t} / \theta_{t}\right)^{h}\left(F_{t}\right)^{1-h},
$$

where $T_{t}^{I}$ is the indirect tax factor defined in footnote 7. By taking the time derivative of the logarithmic version of equation 9 , one obtains an expression that relates the current inflation rate to the current rates of change of unit labor cost, foreign prices, excess commodity demand, and the various tax factors:

$$
p_{t}=h\left(w_{t}-\theta_{t}\right)+(1-h) f_{t}+t_{t}^{I}+h t_{t}^{S}+m\left(v_{t}\right) .
$$

Now, using wage equation 8 , it is possible to obtain a reduced-form expression for the inflation rate that does not directly involve the wage rate:

$$
\begin{aligned}
& \text { 11) } \quad p_{t}=p_{t}^{e}+m\left(v_{t}\right)+\frac{h g X_{t}}{a+b} \\
& +(1-h)\left(f-p^{e}\right)_{t}+\frac{1}{a+b}\left\{h b\left(\lambda-\theta+c^{e}-p^{e}+t^{P}+t^{S}\right)_{t}+[b+a(1-h)] t_{t}^{\prime}\right\} .
\end{aligned}
$$

To interpret equation 11, it helps to combine all of the terms on the second line into a single "cost-push" or "supply-shift" term $z_{t}$, where

$$
\begin{aligned}
z_{t}= & (a+b)(1-h)\left(f-p^{e}\right)_{t}+h b\left(\lambda-\theta+c^{e}-p^{e}+t^{P}+t^{S}\right)_{t} \\
& +[b+a(1-h)] t_{t}^{I} .
\end{aligned}
$$


This allows us to write a more compact version of the reduced-form inflation equation as:

$$
p_{t}=p_{t}^{e}+m\left(v_{t}\right)+\frac{1}{a+b}\left[h g X_{t}+z_{t}\right] .
$$

This is an "expectational" Phillips curve relating actual inflation to expected inflation and the growth and level of excess demand. When the economy is operating at a fixed level of excess demand, with $v_{t}=0$, inflation accelerates $\left(p_{t}>p_{t}^{e}\right)$ whenever $X_{t}$ is positive and decelerates whenever $X_{t}$ is negative. The various cost-push elements allow us to identify two concepts of the natural rate of unemployment.

The "conventional" or "no-shock" natural rate of unemployment is that which is consistent with zero excess demand in the labor market, in the sense that:

$$
U_{t}=U_{t}^{*}-X_{t},
$$

where $U_{t}$ and $U_{t}^{*}$ are, respectively, the actual and no-shock natural rates of unemployment. However, equation 13 implies that the no-shock natural rate of unemployment is compatible with steady inflation only when $z_{t}=0$. An alternative "shock" natural rate concept $\left(U_{t}^{S}\right)$ indicates the unemployment rate consistent with steady inflation when $z_{t} \neq 0$ :

$$
U_{t}^{S}=U_{t}^{*}+\frac{z_{t}}{g h}
$$

The cost-push or supply-shock factors can thus be a cause of inflation, unemployment, or both. If the monetary authority accommodates the shocks in equation 13 by attempting to set $X_{t}=0$, then inflation will accelerate when $z_{t}>0$. If the authority extinguishes the shocks by attempting to set $p_{t}=p_{t}^{e}$, then unemployment will rise above $U_{t}^{*}$, as shown in equation 15. Thus the following four components of $z_{t}$ in equation 12 can be interpreted as causes of inflation, unemployment, or both, depending on the degree of monetary accommodation provided by the monetary authority: first, an increase in the real price of foreign goods expressed in domestic currency $(f-p)$; second, an excess in the growth, $\lambda_{t}$, of the "aspiration" real wage relevant for labor supply over the growth of productivity, $\theta_{t}$, that is relevant for price setting; third, an 
excess in the expected growth of the CPI relevant for labor supply over the product price relevant for labor demand $(c-p)$; and, finally, an increase in any of the three tax factors, personal, payroll, or indirect.

Equation 15 is a useful reminder that inertia or "stickiness" in both real and nominal wages can aggravate unemployment. "Real wage inertia" is a label frequently used for the second item in the preceding list, excessive growth in the "aspiration wage." $z_{t}$ term in equation 15 is positive because of real wage inertia, the amount of unemployment that results, when monetary policy is nonaccommodative, depends inversely on the size of the nominal wage adjustment parameter $g$.

\section{Econometric Specification and Data}

\section{LAGS AND SPECIFICATION OF VARIABLES}

The aim now is to convert the theoretical equations into a form that is suitable for econometric estimation. Issues that require discussion are the treatment of the expected inflation term in equations 8 and 11 , excess demand $\left(v_{t}\right.$ and $\left.X_{t}\right)$, foreign prices, the real wage "push" coming from the $\left(\lambda_{t}-\theta_{t}\right)$ and $\left(c_{t}^{e}-p_{t}^{e}\right)$ terms, and the tax factors, as well as the measurement of the rate of productivity change that matters for price setting, $\theta_{t}$. In the subsequent investigation the definition of variables follows, where possible, the exact form adopted in my previous research. ${ }^{10}$ (The issues are discussed in the next few paragraphs in the same order in which the variables are listed in the later presentation of the statistical results; details on construction of variables and on data sources are presented in appendix A.)

Expectations and Lags. The most straightforward treatment of the expected inflation term in equations like 8 and 11 is to introduce an

9. See Jeffrey D. Sachs, "Wages, Profits, and Macroeconomic Adjustment: A Comparative Study," BPEA, 2:1979, pp. 269-319; "Real Wages and Unemployment in the OECD Countries," BPEA, 1:1983, pp. 255-89; Michael Bruno and Jeffrey D. Sachs, The Economics of Worldwide Stagflation (Harvard University Press, 1985).

10. Gordon, "Flexible Exchange Rates"; Gordon and King, "'Output Cost of Disinflation." 
autoregressive lag distribution. This lagged inflation term is open to two interpretations. One is to treat it directly as a proxy for price expectations on the assumption that these expectations are formed adaptively. This interpretation is so widely adopted that the label "expectations-augmented Phillips curve" is conventionally applied to equations explaining wage or price change in which one or more lagged price variables appear. But it is open to the criticism that adaptive expectations are not rational and that rational agents would use all available information on the other variables in equation 11 in forming their inflation expectations. I prefer a second interpretation: the lagged inflation terms represent the inertia of wage- and price-setting institutions, especially implicit and explicit contracts. In this context the lagged inflation terms express a mechanical connection between current and past inflation caused by inertia, without implying anything about the formation of expectations. The terminology "augmented Phillips curve" thus seems more appropriate than the more usual "expectations-augmented Phillips curve."

The treatment of the lagged inflation variable presented below is somewhat unusual: lagged inflation terms are entered twice, with one set of coefficients before 1967 and another beginning in 1967. My previous research called for this "split" lag distribution to reflect evidence that the mean lag on past inflation shortened substantially (from at out twelve to seven quarters) beginning in 1967 , perhaps as a result of the increased degree of indexation of wage contracts. For consistency I continue the practice here, although the passage of time has added extra quarters to the post-1966 period and reduced the statistical significance of this coefficient shift.

The Demand Pressure Variables. The level of excess labor demand appears in equations 8 and 11, while the change of excess commodity demand appears in equations 10 and 11. Many previous studies have designated the unemployment rate or its inverse as the sole demand pressure variable. However, the regular Okun's law correlation between unemployment and detrended output (the "output ratio") creates collinearity when unemployment is entered as a proxy for excess labor supply and the output ratio is entered as a proxy for excess commodity demand. Because, as I discovered in my 1977 paper, a wage equation containing the output ratio performs as well as, or better than, an equation containing the unemployment rate, the econometric work that follows uses as the sole demand variable the output ratio developed in 
my 1984 paper, entered as the current and four lagged values. ${ }^{11}$ Implications of the results for the natural rate of unemployment can be calculated easily by using the Okun's law coefficients from my 1984 paper to convert output gaps into unemployment gaps. The inclusion of lags allows both level and rate-of-change effects to be present simultaneously, since the typical pattern is for positive coefficients on the output ratio to be followed by negative coefficients (implying a rate-of-change effect), with a positive and significant sum of coefficients.

Productivity Deviation. Reflecting the influence of research on markup price behavior by the late Otto Eckstein and others, the productivity variable relevant for price setting and for labor demand is labeled "standard productivity"; the ratio of the wage rate to standard productivity, "standard unit labor cost." 12 In the past a fruitful specification of the change in standard productivity has been a weighted average of the actual growth rate of productivity, $\theta_{t}^{A}$, and of a productivity growth trend, $\theta_{t}^{*}$, as follows:

$$
\begin{aligned}
\theta_{t} & =e \theta_{t}^{A}+(1-e) \theta_{t}^{*} \\
& =\theta_{t}^{*}+e\left(\theta_{t}^{A}-\theta_{t}^{*}\right) .
\end{aligned}
$$

This specification replaces the single productivity variable, $\theta_{t}$, in the theoretical analysis above with a productivity trend, $\theta_{t}^{*}$, and an additional variable, the deviation of actual productivity growth from that trend $\left(\theta_{t}^{A}-\theta_{t}^{*}\right)$. This "productivity deviation" variable comes from my 1984 paper, which developed time series for trends between benchmarks, as well as cyclical deviations from those trends, for several components of GNP, including productivity and labor force participation.

Relative Food and Energy Prices. In principle the relative foreign price term in equation 11 should include any change in the relative price of inputs to the domestic economy, including changes in the relative price of domestic and foreign raw materials. In previous research I have used the most readily available measure of the impact of changes in the relative price of food and energy, the difference between the respective

11. This is precisely the form used in Gordon and King, "Output Cost of Disinflation." One of the minor differences in Gordon, "Flexible Exchange Rates," is the use of the current level and current change in Perry's weighted unemployment rate in place of current and lagged values of the output ratio.

12. See the paper by Otto Eckstein and Gary Fromm, "The Price Equation," American Economic Review, vol. 58 (December 1968), pp. 1159-83. 
rates of change of the national accounts deflators for personal consumption expenditures and for personal consumption net of expenditures on food and energy. The advantages of this measure are that it incorporates food and energy products with weights reflecting their importance in final spending, and that it assumes a value of zero when the relative prices of food and energy are constant. However, the estimated coefficient cannot be interpreted as the effect of a rise in food and energy prices. Rather, it should correspond roughly to the weight of consumption in the total fixed-weight GNP deflator.

Relative Foreign Prices. A lively area of current concern is the impact on domestic inflation of a hypothetical depreciation of the dollar to follow the substantial appreciation that occurred between late 1980 and early 1985. One of my previous papers ("Flexible Exchange Rates") included as a variable only the effective exchange rate of the dollar; another (Gordon-King) included both the exchange rate and the relative price of imports. Since the exchange rate and relative import price measure the same phenomenon and tend to move together, it is preferable to include only one of the two variables in an inflation equation. When used alone, the coefficient on the exchange rate proved to be quite unstable, declining substantially when the end of the sample period was extended from 1980 to 1984 . Thus, all equations in this paper include the change in the relative price of nonfood, nonfuel imports and exclude the change in the effective exchange rate. This change in specification seems to avoid coefficient instability and is compatible with the view of most economists, who feel that the exchange rate should influence domestic inflation only to the extent that it changes the relative price of imports. ${ }^{13}$

Relative Changes in Consumer Prices. The theoretical discussion calls for the difference between the expected rates of change of consumer and producer prices to be entered into both the wage equation 8 and the reduced-form price equation 11 . This variable is measured by the difference between the growth rates of the CPI and the fixed-weight GNP deflator, with four lagged terms included. It is one of the three variables (the other two are personal and indirect tax rates) suggested by the model developed above that were not included in my earlier papers.

Effective Minimum Wage. An increase in the effective minimum

13. For the period after 1966, the price index for nonfood, nonfuel imports was kindly provided by Wing T. Woo. It replaces the fixed-weight import deflator used in Gordon and King, "Output Cost of Disinflation." 
wage, defined as the nominal minimum wage rate divided by nominal average hourly earnings, is assumed to restrict effective labor supply and, implicitly, to raise the "aspiration" real wage in the labor supply function $\left(\Lambda_{t}\right)$. This variable is included in exactly the same form as in the earlier papers.

Tax Changes. Several of my earlier papers have included changes in the effective payroll tax in equations for wage and price change. This variable is used here with an improved definition, suggested by a recent critique of research on this topic. ${ }^{14}$ Measures of the change in effective personal and indirect tax rates were included in several of my papers written in the early 1970s but have been dropped in more recent research. These are restored here, since they are called for by equations 8,10 , and 11. The effective personal tax rate is defined as the ratio of personal tax collections to personal income, and the effective indirect tax rate is defined as indirect business tax receipts divided by private GNP.

Nixon Controls. The impact of the price controls imposed by the Nixon administration is assessed with a pair of dummy variables, specified to show the cumulative displacement of the price level by the controls and the extent of its rebound after controls ended. The timing and definition of these dummy variables here is the same as it was in both "Flexible Exchange Rates", and Gordon-King.

Real-Wage Inertia. The theoretical specification includes a term for the difference in the growth rates of the aspiration real wage and standard productivity. If, following a sustained slowdown in productivity growth, workers attempt to maintain the previous growth rate of real wage rates, then the natural unemployment rate that allows for shock effects, as in equation 15 above, will be increased. Because the U.S. productivity slowdown worsened after 1972, I attempt to identify real-wage inertia by estimating coefficients for dummy variables that come into effect after 1972. To avoid confounding this factor with the impact of other variables, I allow the real-wage inertia dummy variables to remain in effect for four years each (1973-76, 1977-80, and 1981-84). These dummy variables measure any source of inflationary pressure that is not captured by the other variables-in addition to real-wage inertia, such variables as the replacement ratio and coverage of the unemployment insurance system, rules and benefit levels of the welfare system, and general

14. Richard F. Dye, "Evidence on the Effects of Payroll Tax Changes on Wage Growth and Price Inflation: A Review and Reconciliation, " Working Paper 34 (U.S. Social Security Administration, April 1984). 


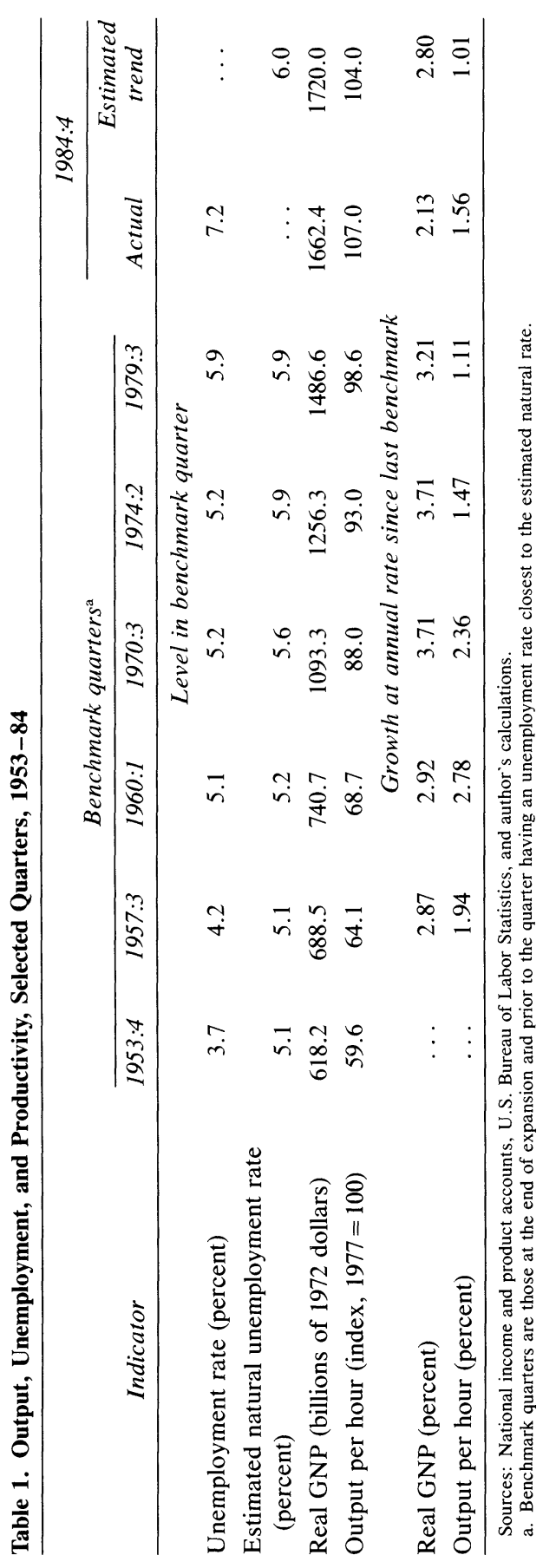


attitudes of successive presidential administrations regarding labor unions.

The form of the estimated equations can be summarized by combining all the supply-shift terms into a single variable, $z_{t}$, as in equation 12. Then the right-hand side variables consist simply of a set of lagged price or wage terms, current and lagged values of the output ratio $\left(\hat{\mathrm{Q}}_{t}=\ln Q_{t}-\ln Q_{t}^{*}\right)$, current and lagged differences between the growth rates of actual and trend productivity $\left(\theta_{t}^{A}-\theta_{t}^{*}\right)$, and current and/or lagged values of the various supply-shift terms in the wage equation, $z_{i t}^{\text {w }}$

$$
\begin{aligned}
w_{t}-\theta_{t}^{*}= & \alpha_{1}(L) p_{t}+\alpha_{2}(L) \hat{Q}_{t} \\
& +\alpha_{3}(L)\left(\theta_{t}^{A}-\theta_{t}^{*}\right)+\sum_{i} \alpha_{4 i}(L) z_{i t}^{w}+\epsilon_{t}^{w} .
\end{aligned}
$$

The markup equation for the change in prices relative to wages can be written in a parallel fashion as:

$$
\begin{aligned}
p_{t}= & \beta_{1}(L)\left(w_{t}-\theta_{t}^{*}\right)+\beta_{2}(L) \hat{Q}_{t} \\
& +\beta_{3}(L)\left(\theta_{t}^{A}-\theta_{t}^{*}\right)+\sum_{i} \beta_{4 i}(L) z_{i t}^{D}+\epsilon_{t}^{p} .
\end{aligned}
$$

To simplify the presentation of the reduced-form, the complex set of lagged coefficients is relabeled [for example, $\gamma_{1}(L)=\beta_{1}(L) \alpha_{1}(L)$ ], and an influence of current price change on current wage change in equation 17 is ruled out. Also, the two supply-shock vectors $\left(z_{t}^{w}\right.$ and $\left.z_{t}^{p}\right)$ are combined into one, $z_{t}$. The resulting reduced-form can be written:

$$
\begin{aligned}
p_{t}= & \gamma_{1}(L) p_{t-1}+\gamma_{2}(L) \hat{Q}_{t} \\
& +\gamma_{3}(L)\left(\theta_{t}^{A}-\theta_{t}^{*}\right)+\sum_{i} \gamma_{4 i}(L) z_{i t}+\beta_{1}(L) \epsilon_{t}^{w}+\epsilon_{t}^{p} .
\end{aligned}
$$

In each of equations 17,18 , and 19 , the " $z$ " variables refer to various components of the supply-shift vector, as discussed above. In the results reported below in the empirical work, equations are estimated with the full set of components of " $z$ " and with the subset that corresponds to that in earlier research.

THE NATURAL OUTPUT SERIES

Data for the dependent and independent variables are neither exhibited nor discussed in the body of the paper, but are displayed in appendix B. Table 1 provides a brief introduction to the method used in the 1984 
paper to develop the series for the output ratio. The benchmark quarters shown in the table are those at the end of economic expansions immediately prior to the quarter having an unemployment rate closest to the previously estimated natural rate series. The one-quarter lag was chosen to take account of lags in the adjustment of labor input to changes in output. This lag accounts for the fact that the unemployment rate in the first two benchmark quarters shown in table 1 is substantially below the estimated natural unemployment rate of 5.1 percent in both 1954 and 1957 (the actual unemployment rate in the subsequent quarter was 5.2 percent in 1954:1 and 4.9 percent in 1957:4). The level of natural real GNP is defined as equal to actual real GNP in the benchmark quarters, and table 1 shows the implied growth rate of natural real GNP for the intervals through 1979:3.

For the period 1979-84 an iterative procedure was used to find the growth rate of natural real GNP that produced the best fit in an Okun's law equation relating the actual unemployment rate to the implied output ratio. Thus the series for natural real GNP and the output ratio after 1979 assumes that the natural unemployment rate has been constant at about 6.0 percent. One of the research tasks of this paper is to determine whether the corresponding output ratio is consistent with steady inflation in the absence of supply shocks, or whether a lower or higher output ratio is required to maintain steady inflation.

Table 1 also exhibits the level in benchmark quarters and rate of change between benchmark quarters of nonfarm private output per hour. This rate of change is the $\theta_{t}^{*}$ series used to define the productivity growth deviation series. As shown in the bottom line of table 1, the "natural" productivity growth series derived in the 1984 paper grows at a rate of 1.01 percent per year between 1979 and 1984, that is, more slowly than the actual growth rate of 1.56 percent.

\section{Reduced-Form Inflation Equations}

\section{ESTIMATES AND CONSTRAINTS}

The basic estimation results for the reduced-form equations in format 19 are displayed in table 2 . The first two columns cover the sample period 
1954:2-1980:4, the same sample period used in the earlier papers where the specification was developed. The remaining four columns extend the sample period to 1984:4. The first three columns, labeled "Earlier Specification," contain just those variables that were included in the earlier papers and exclude the three additional variables suggested by the model developed above: the relative change in the CPI, and changes in the personal and indirect tax factors. Lag lengths for every variable are chosen to correspond exactly to those in the Gordon-King paper and are not varied in any of the equations presented in the rest of this paper. ${ }^{15}$ The three new variables introduced in columns 4 through 6 are entered as four lagged values, excluding the current value, to correspond to the previous treatment of the payroll tax and the minimum wage.

The figur $s$ shown in the table are sums of coefficients. Asterisks desigrate significance levels of these sums, as shown in the notes to the table. Columns 1 and 2 differ only in that the latter imposes the constraint that the coefficients on lagged inflation sum to unity. This constraint is required to determine the "no-shock natural level" of real GNP that is consistent with steady inflation when all other variables are set to zero. Sums of coefficients are similar to those in previous research, with insignificant sums of coefficients on the payroll tax and Nixon controls "on" variables in both columns, and on the import price in column 1.

In column 3 the earlier specification (excluding the three new variables) is estimated for the extended sample period through 1984:4. Coefficient changes are uniformly minor. Column 4 adds the three variables (that is, the relative consumer price change and the two additional tax variables), with uniformly insignificant sums of coefficients. Only when a constrained version of this specification is estimated in column 5 is the consumer price variable significant even at the 10 percent level, with a small but plausible coefficient of 0.20 . Otherwise, the complete specification in columns 4 and 5 yields no important changes in coefficients already present in column 3 , except for the unstable and highly insignificant coefficients on the payroll tax.

Finally, column 6 enters dummy variables for three four-year periods after 1972:4. All variables are insignificant, even at the 10 percent significance level. This finding constitutes the main piece of evidence in

15. The only exception is in table 5, where three extra lags on the output ratio are included. 


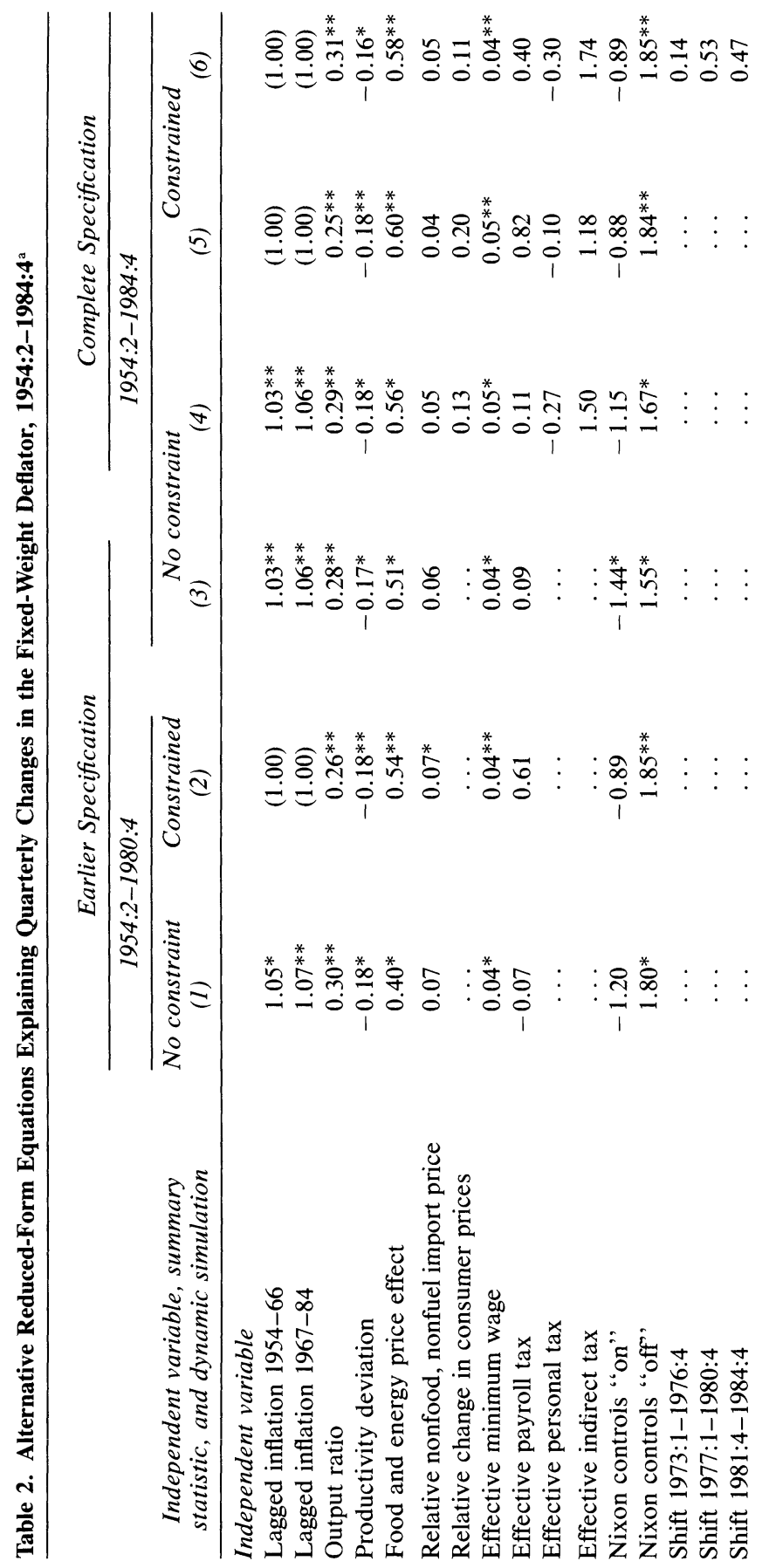




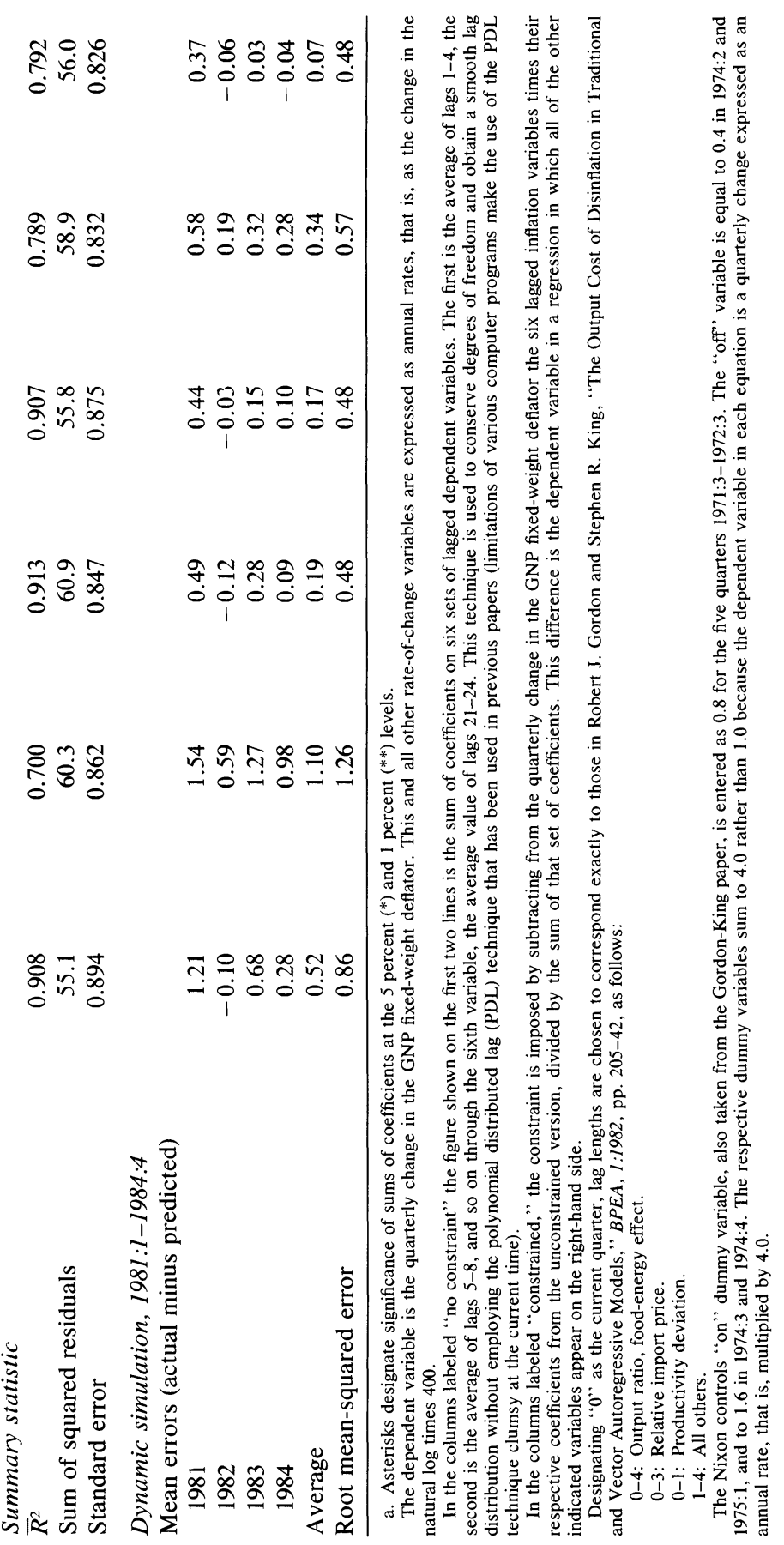


the paper that there has been no significant shift in the natural rate of unemployment from the earlier series used to create the output ratio (that natural unemployment rate series has remained on a plateau of about 6.0 percent since 1974).

Some readers may prefer to ignore significance levels and inquire into the implications of the positive values of the dummy variables in column 6 . These introduce a constant term into the equation that is otherwise not present. Consider a simplified version of the inflation equation containing a constant term as follows:

$$
p_{t}=\alpha_{0}+\alpha_{1} p_{t-1}+\alpha_{2} \hat{Q}_{t} .
$$

If the coefficient on lagged inflation, $\alpha_{1}$, is unity, a constraint imposed on the sums of coefficients on lagged inflation in column 6 of table 2, then the noninflationary output ratio is not $\hat{Q}_{t}=0$ but rather

$$
\tilde{Q}_{t}=-\frac{\alpha_{0}}{\alpha_{2}} .
$$

If there is an Okun's law relationship linking the unemployment rate with movements in the output ratio (for example, $U_{t}=U_{t}^{*}-j \hat{Q}_{t}$ ), then a nonzero value for the constant term in equation 20 implies that the natural rate of unemployment is not the value $U_{t}^{*}$ but rather

$$
\tilde{U}_{t}^{*}=U_{t}^{*}+\frac{j \alpha_{0}}{\alpha_{2}} .
$$

Taking the value $j=0.45$ from the 1984 paper, a value of $\tilde{U}_{t}^{*}$ of 6.7 percent is implied by column $6[6.7=6.0+(0.45)(0.47 / 0.31)]$. However, the low statistical evidence of the dummy shift variables in column 6 supports the view that the relevant natural rate series is still 6.0 percent.

The bottom section of table 2 exhibits results from dynamic simulations of the various equations over the 1981-84 period. Shown are the average error for each of the four years in the simulation period, the average error at an annual rate for the full four-year period, and the root mean-squared error (RMSE) over the full period. Since the sample period of the equations in columns 1 and 2 ends in 1980, the simulation errors shown in those columns extend four years beyond the sample period. The mean error in column 1 is 0.52 percent at an annual rate, that is, the actual values are on average half a point higher than the 
Figure 1. Simulation of Unconstrained Reduced-Form Inflation Equation, 1976:1-1984:4 Inflation rate (percent)

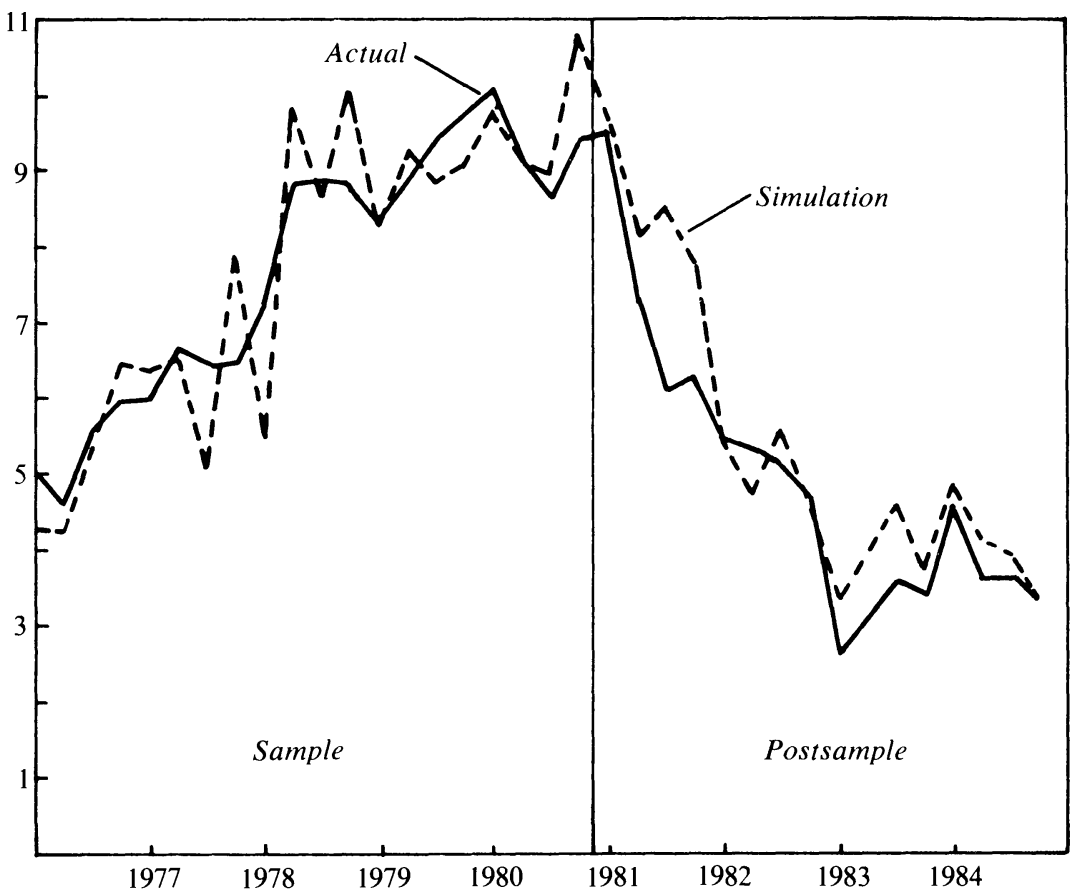

Source: Table 2, equation 1.

predicted values, indicating that the equation predicts too little inflation. But the errors are not large, with an error in 1984 of only 0.28 of a percentage point, and the RMSE is actually less than the sample-period standard error. The errors in column 2 are larger, since the constraint imposes a sum of coefficients of unity (rather than the estimated value of 1.07) on the lagged dependent variable, allowing less of the high inflation of 1979-80 to feed through to the 1981-84 simulation period. Figure 1 exhibits the actual and fitted values of the equation in column 1 of table 2 for the last five years of its sample period and for the four years of the dynamic simulation. By a reassuring coincidence, the simulated values are precisely on target in 1984:4, after four years in which the simulation endogenously generates values of the lagged dependent variable. 


\section{STABILITY TESTS}

The reduced-form inflation equation appears to have remained stable over the full 1954-84 sample period. In a test of whether the additional sixteen quarters shift the structure of the original specification in table 2 , column 1 , the $F(16,85)$ ratio is a highly insignificant 0.51 . Table 3 reports two other experiments that examine stability before and after 1967:1, the date used to break the two lag distributions on the dependent variable. In previous research this date was roughly halfway through the 1954-80 sample period and is used here to maintain consistency. The tests in table 3 have been repeated for a break date of 1969:3 with identical results.

The basic unconstrained "truncated" equation in column 1 of table 3 is the same as in table 2 , column 4 , but with the three insignificant tax variables excluded in order to conserve on degrees of freedom. ${ }^{16}$ Column 2 of table 3 adds one variable, the output ratio times a dummy variable for 1967-84, to test for a change in the slope of the Phillips curve. This coefficient in line 4 is very small and highly insignificant. Columns 4 and 5 display the results when the truncated unconstrained equation is estimated for sample periods before and after 1967:1. The $F(24,61)$ ratio for the significance of a structural shift at that date is an insignificant 0.85 . The sums of coefficients on lagged inflation and on the output ratio are quite similar in the two subsamples, while the coefficients on the various supply-shift terms are quite unstable. An interesting aspect of column 4 is that the sum of coefficients on the lagged dependent variable for 1954-66 is slightly greater than unity, in contrast to my impression, and that of others, at the first Brookings Panel meeting in 1970 that the sum of the coefficients was well below unity (the discussion at that time was framed in terms of wage equations, not reduced-form price equations).

Column 3 tests for a shift in the coefficient on the relative import price variable after 1980 . This column displays an equation that is identical to column 1, except that it adds another variable, the import price change times a dummy variable for the four years $1981-84$, to test for a change

16. The other variables are included on the grounds that they are significant in at least one of the columns of table 2 . The relative consumer price variable is significant in a wage equation that is not reported. 
Table 3. Sensitivity of Truncated Equation to Sample Splits, 1954:2-1984:4

\begin{tabular}{|c|c|c|c|c|c|}
\hline \multirow[b]{2}{*}{$\begin{array}{l}\text { Independent variable } \\
\text { and summary statistic }\end{array}$} & \multirow[b]{2}{*}{$\begin{array}{c}\text { Basic } \\
\text { truncated } \\
\text { equation } \\
\text { (1) }\end{array}$} & \multirow[b]{2}{*}{$\begin{array}{l}\text { Split } \\
\text { output } \\
\text { ratio } \\
(2)\end{array}$} & \multirow[b]{2}{*}{$\begin{array}{l}\text { Split } \\
\text { import } \\
\text { price } \\
\text { (3) }\end{array}$} & \multicolumn{2}{|c|}{ Sample period } \\
\hline & & & & $\begin{array}{c}1954: 2- \\
1966: 4 \\
\text { (4) }\end{array}$ & $\begin{array}{c}1967: 1- \\
1984: 4 \\
(5)\end{array}$ \\
\hline \multicolumn{6}{|l|}{ Independent variable } \\
\hline Lagged inflation 1954-66 & $1.06^{* *}$ & $1.07^{* *}$ & $1.06^{* *}$ & $1.05^{* *}$ & \\
\hline Lagged inflation 1967-84 & $1.05^{* *}$ & $1.05^{* *}$ & $1.04 * *$ & $\ldots$ & $1.06^{* *}$ \\
\hline Output ratio & $0.27 * *$ & $0.30^{* *}$ & $0.28^{* *}$ & 0.23 & $0.28 * *$ \\
\hline Output ratio extra effect $1967-84$ & & -0.02 & $\ldots$ & $\ldots$ & $\ldots$ \\
\hline Productivity deviation & $-0.16^{*}$ & $-0.16^{*}$ & $-0.17 *$ & -0.14 & $-0.28^{*}$ \\
\hline Food and energy price effect & $0.47^{*}$ & 0.48 & 0.43 & 0.65 & 0.02 \\
\hline Relative import price & 0.06 & 0.06 & 0.03 & 0.05 & 0.13 \\
\hline Extra import price effect $1981-84$ & $\ldots$ & $\ldots$ & -0.05 & & \\
\hline Relative changes in consumer prices & 0.13 & 0.13 & 0.15 & 0.15 & 0.29 \\
\hline Effective minimum wage & $0.04^{*}$ & $0.04 *$ & $0.04^{*}$ & $0.06^{*}$ & 0.01 \\
\hline Nixon controls "on" & $-1.33^{*}$ & $-1.30^{*}$ & $-1.28 *$ & $\ldots$ & -1.10 \\
\hline Nixon controls "off" & $1.67^{*}$ & $1.59^{*}$ & $1.59^{*}$ & $\cdots$ & 1.62 \\
\hline \multicolumn{6}{|l|}{ Summary statistic } \\
\hline $\bar{R}^{2}$ & 0.915 & 0.911 & 0.912 & 0.430 & 0.871 \\
\hline Sum of squared residuals & 59.2 & 58.6 & 58.3 & 15.0 & 29.3 \\
\hline Standard error & 0.834 & 0.856 & 0.848 & 0.846 & 0.856 \\
\hline
\end{tabular}

Source: Table 2, column 4 .

a. All details are the same as in table 2, except that all equations in this table exclude the three tax variables.

in the slope of the import price effect. This shift effect is negative, indicating no positive response of inflation to changes in relative import prices after 1980. Such a shift is consistent with the finding, not reported here, that the coefficient on changes in the effective exchange rate shifts from positive to negative after 1980 . However, the shift coefficient in table 3 on import prices is far from statistical significance, so there seems to be no case for respecifying the basic equation in column 1 .

\section{HISTORICAL DECOMPOSITION}

The implications of the reduced-form inflation equation become clearer in table 4 , which presents a historical decomposition of the contribution of different explanatory variables to the inflation rate in three dynamic simulations beginning, respectively, in 1964:1, 1971:3, and 1981:1. The top three lines of the table report changes between the beginning and end of each simulation period in the actual and simulated 
Table 4. Historical Decomposition of Change in Inflation Rate in Dynamic Simulations, Selected Periods, 1964:4-1984:4

Percent

\begin{tabular}{lccc}
\hline \multicolumn{1}{c}{ Change } & $\begin{array}{c}1964: 4-1971: 2 \\
(1)\end{array}$ & $\begin{array}{c}1972: 2-1980: 4 \\
(2)\end{array}$ & $\begin{array}{c}1981: 4-1984: 4 \\
(3)\end{array}$ \\
\hline Actual change & 3.49 & 5.97 & -4.43 \\
Fitted change & 3.67 & 6.29 & -4.05 \\
Error & -0.18 & -0.32 & -0.38 \\
Change in fitted value & attributable to: & & \\
Output ratio & 3.28 & -2.44 & -2.76 \\
Food-energy prices & -0.08 & 2.90 & -0.81 \\
Import prices & -0.13 & 1.59 & -0.67 \\
Minimum wage & -0.32 & 0.12 & -0.34 \\
Consumer prices & 0.12 & 0.87 & -0.16 \\
Residual $^{\text {a }}$ & 0.80 & 3.25 & 0.69 \\
\hline
\end{tabular}

Source: Table 3, column 1. All figures in this table refer to four-quarter moving averages ending on dates shown. a. Residual includes effects of Nixon controls, productivity deviation, initial conditions, and interaction effects.

inflation rate. Errors in the simulated changes for 1964-71, 1972-80, and 1981-84 are relatively small, allowing use of the simulations to calculate the effect of the variables on inflation during these three periods.

The major source of the acceleration of inflation in the late 1960s was the recurring positive value of the output ratio over twenty-five straight quarters between 1964:1 and 1970:1. In the 1970s the food-energy effect was the main culprit, though substantial additional pressure came from import prices and the relative CPI term, balanced only in part by a decline in the output ratio. Since 1980 the single greatest contribution to disinflation has been made by a low output ratio, that is, by unemployment above the natural rate. Also influential have been declines in the relative prices of food and energy and of nonfood, nonfuel imports, as well as a little-noticed decline in the effective minimum wage since early 1981, when the nominal minimum wage was last increased.

To some extent it is artificial to separate the output ratio and foodenergy effects in this way, since part of the beneficial food-energy effect in the 1980s may have represented a response to the worldwide recession. However, the Gordon-King paper found no aggregate demand response of food and energy prices. A regression for 1960-84 of changes in the food-energy variable on its own lagged values, and current and lagged values of the exchange rate, import prices, and the output ratio, also finds a near-zero and insignificant sum of coefficients on the output ratio. 
THE MONEY SUPPLY AND INFLATION

The next question is how to take into account the famous edict of Milton Friedman: "Inflation is always and everywhere a monetary phenomenon." 17 Estimating an equation in which the inflation rate is regressed on current and lagged changes in the money supply would omit the various supply-shift variables included in our basic specification. What is needed is a more precise test of the role of monetary growth as a channel by which aggregate demand changes are transmitted to the inflation rate. The basic specification includes current and lagged values of the output ratio, $\hat{Q}_{t}$, as the only demand variable. Results based on a real variable expressed in levels, as in this specification, cannot be directly compared with an alternative specification that enters the rate of change of the nominal money supply.

Fortunately, it is quite easy to devise a "fair test" of the alternative hypotheses by noting that the basic specification can be transformed into an expression in which the growth rate of nominal GNP appears in addition to the level of the output ratio. An identity links the current output ratio to its lagged value, the growth rate of nominal GNP in excess of the growth of natural real GNP $\left(\hat{y}_{t}=y_{t}-q_{t}^{*}\right)$, and the inflation rate:

$$
\hat{Q}_{t} \equiv \hat{Q}_{t-1}+\hat{y}_{t}-p_{t}
$$

In what follows, it will also be helpful to write an additional identity that decomposes "excess" nominal GNP growth into the sum of "excess" money growth and actual velocity growth:

$$
\hat{y}_{t} \equiv \hat{m}_{t}+v_{t} \quad\left(\text { where } \hat{m}_{t}=m_{t}-q_{t}^{*}\right) .
$$

To see how nominal GNP and money growth implicitly enter the basic specification, I write a simplified version of the model that omits supplyshift variables, as in equation 20 above, and excludes the constant term, but includes the rate of change of the output ratio as well as the level. This extra rate-of-change term is justified by the fact that the coefficients

17. Milton Friedman, Inflation: Causes and Consequences (Bombay: Asia Publishing House, 1963), reprinted in Dollars and Deficits (Prentice-Hall, 1968), p. 39. 
on the current and lagged output ratio in tables 2 and 3 are positive and then negative (with a positive sum), indicating that both a level and rateof-change effect are important:

$$
p_{t}=p_{t-1}+\gamma_{1} \hat{Q}_{t}+\gamma_{2}\left(\hat{Q}_{t}-\hat{Q}_{t-1}\right) .
$$

A recursive substitution of identity 23 into equation 25 yields:

$$
p_{t}=\frac{1}{1+\gamma_{1}+\gamma_{2}}\left[\left(1-\gamma_{1}\right) p_{t-1}+\left(\gamma_{1}+\gamma_{2}\right) \hat{y}_{t}+\gamma_{1} \hat{y}_{t-1}+\gamma_{1} \hat{Q}_{t-2}\right]
$$

Note that the sum of coefficients on $p_{t-1}, \hat{y}_{t}$, and $\hat{y}_{t-1}$ equals 1.0.

What does this transformation imply about the connection between inflation and monetary growth? We can use identity 24 to replace excess nominal GNP growth in equation 26 by the sum of excess monetary growth and actual velocity growth:

$$
\begin{aligned}
p_{t}= & \frac{1}{1+\gamma_{1}+\gamma_{2}}\left[\left(1-\gamma_{1}\right) p_{t-1}\right. \\
& \left.+\left(\gamma_{1}+\gamma_{2}\right)\left(\hat{m}_{t}+v_{t}\right)+\gamma_{1}\left(\hat{m}_{t-1}+v_{t-1}\right)+\gamma_{1} \hat{Q}_{t-2}\right] .
\end{aligned}
$$

This final equation exhibits an important implication of the basic augmented Phillips curve approach-the effect on inflation of current and lagged excess money growth should be the same as that of velocity growth. In other words, what matters is excess nominal GNP growth, with no special role for monetary growth different from the role of velocity growth.

Table 5 displays the results of estimating equations 25,26 , and 27 with all of the same supply-shift variables as before. Because advocates of a direct link between money and inflation often refer to a lag of 18 to 24 months for the monetary effect to take place, the current and seven lagged values of the output ratio are included in equation 25 , with results displayed in column 1 of table 5 . There is virtually no difference between these results and the corresponding equation in table 3 , column 1 , which enters four instead of seven lags on the output ratio. Column 2, table 5 , corresponds to the specification in 26 and shows results for the version in which recursive substitution allows nominal GNP changes to replace current and lagged values of the output ratio. Both excess nominal GNP changes and the output ratio lagged eight periods are highly significant, with little important change in the other variables. The estimated sums of coefficients are consistent with the requirement of equation 26 that 
Table 5. Nominal GNP and Monetary Growth as Alternative Explanatory Variables, 1954:2-1984:4a

\begin{tabular}{|c|c|c|c|c|}
\hline $\begin{array}{l}\text { Independent variable, summary } \\
\text { statistic, and dynamic simulation }\end{array}$ & $\begin{array}{c}\text { Basic } \\
\text { truncated } \\
\text { equation } \\
\text { (1) }\end{array}$ & $\begin{array}{l}\text { Nominal } \\
\text { GNP } \\
\text { growth } \\
(2)\end{array}$ & $\begin{array}{l}\text { Monetary } \\
\text { and velocity } \\
\text { growth } \\
\text { (3) }\end{array}$ & $\begin{array}{c}\text { Monetary } \\
\text { growth } \\
\text { (4) }\end{array}$ \\
\hline \multicolumn{5}{|l|}{ Independent variable } \\
\hline Lagged inflation 1954-66 & $1.06^{* *}$ & $0.57^{* *}$ & $0.65^{* *}$ & $1.27^{* *}$ \\
\hline Lagged inflation 1967-84 & $1.07 * *$ & $0.64^{* *}$ & $0.63 * *$ & $0.57^{* *}$ \\
\hline Output ratio (lags $0-7$ ) & $0.33^{* *}$ & $\ldots$ & $\ldots$ & $\ldots$ \\
\hline Output ratio (lag 8) & $\ldots$ & $0.24 * *$ & 0.19 & -0.06 \\
\hline Excess nominal GNP growth & $\cdots$ & $0.44^{* *}$ & $\cdots$ & $\cdots$ \\
\hline Adjusted money growth & . . & . . & $0.45 * *$ & 0.56 \\
\hline Velocity growth & . & $\ldots$ & $0.38^{* *}$ & . . \\
\hline Productivity deviation & $-0.19 * *$ & $-0.24^{* *}$ & $-0.27^{* *}$ & -0.04 \\
\hline Food and energy price effect & $0.46^{*}$ & 0.33 & 0.42 & $1.03^{* *}$ \\
\hline Relative nonfood, nonfuel import prices & 0.05 & 0.05 & 0.04 & 0.03 \\
\hline Relative change in consumer prices & 0.13 & 0.10 & 0.11 & 0.20 \\
\hline Effective minimum wage & 0.03 & 0.03 & 0.03 & $0.07 * *$ \\
\hline Nixon controls "on" & $-1.37^{*}$ & -1.13 & -0.92 & -0.96 \\
\hline Nixon controls "off" & $1.76^{* *}$ & $1.31^{*}$ & 1.17 & $1.36^{*}$ \\
\hline \multicolumn{5}{|l|}{ Summary statistic } \\
\hline $\bar{R}^{2}$ & 0.917 & 0.933 & 0.933 & 0.902 \\
\hline Sum of squared residuals & 56.1 & 44.8 & 40.0 & 64.8 \\
\hline Standard error & 0.827 & 0.744 & 0.740 & 0.894 \\
\hline \multicolumn{5}{|l|}{ Dynamic simulation, 1981:1-1984:4 } \\
\hline \multicolumn{5}{|l|}{ Mean errors (actual minus predicted) } \\
\hline 1981 & 0.50 & 0.37 & 0.37 & 0.38 \\
\hline 1982 & -0.00 & 0.03 & -0.08 & -0.57 \\
\hline 1983 & 0.12 & -0.02 & 0.04 & -0.83 \\
\hline 1984 & 0.04 & -0.07 & -0.01 & -0.21 \\
\hline Average & 0.16 & 0.08 & 0.08 & -0.31 \\
\hline Root mean-squared error & 0.45 & 0.46 & 0.46 & 0.72 \\
\hline
\end{tabular}

Source: Equations 25, 26, and 27.

a. All details are the same as in table 2, except that all equations in this table exclude the three tax variables. The equation in column 1 is the same as that in table 3, column 1, except that lagged terms on the output ratio for lags 5 to 7 are included here in addition to lags 0 to 4 . The dependent variable is the rate of change in the fixed-weight GNP deflator.

the coefficients on nominal variables (lagged inflation and current and lagged nominal GNP growth) must sum to unity. The improvement in the fit of the statistics from column 1 to column 2 does not necessarily indicate that the nominal GNP version is superior to the basic specification, since current-period nominal GNP changes may include some contemporaneous response to innovations in the price process.

Column 3 is identical to column 2 but drops the restriction that the 
coefficients on excess monetary growth and actual velocity growth must be identical. However, the restriction is accepted, since the $F(8,73)$ ratio for the significance of the extra variables in column 3 is only 1.09. Column 4 shows the sharp deterioration in fit that occurs when the velocity terms are omitted, leaving current and lagged monetary growth as the only demand variable (in addition to the output ratio lagged eight quarters). The sum of squared residuals jumps by more than 50 percent in column 4 as compared with column 3 , and the $F(8,73)$ ratio for the significance of the velocity terms in column 3 is a highly significant 5.66. The RMSE of the dynamic simulation in the "money-only" version of column 4 is more than 50 percent higher than the errors in column 2 or 3 , with a particularly large error in 1982 , when velocity fell sharply.

These results provide strong support for the augmented Phillips curve approach as opposed to an alternative that singles out money as having a unique connection with inflation. Milton Friedman's famous edict should be rephrased: "Inflation is always and everywhere an excess nominal GNP phenomenon, at least in the long run."

\section{Policy Implications}

\section{OUTPUT SACRIFICE RATIOS}

A major focus of the Gordon-King paper, which used the same basic specification of the reduced-form version of the augmented Phillips curve as I do here, was on the output "sacrifice ratio." This is the cumulative output cost of disinflation, measured as the present discounted value of the cumulative negative values of the output ratio for a 1 percentage point permanent reduction in the inflation rate. The sacrifice ratios calculated in the Gordon-King paper were as low as 3.0 and contrasted sharply with the higher ratio of 10 that had been suggested by the research of Arthur Okun. ${ }^{18}$

The reason for the lower estimate in the Gordon-King paper was the inclusion of an "auxiliary model" that supplemented the reduced-form inflation equation with equations for the exchange rate, import prices, and the food-energy effect. The simulated movement of those terms in

18. Arthur M. Okun, "Efficient Disinflationary Policies," American Economic Review, vol. 68 (May 1978, Papers and Proceedings, 1977), pp. 348-52. 
Table 6. Alternative Output Sacrifice Ratios in a Twelve-Year Dynamic Simulation

\begin{tabular}{|c|c|c|c|}
\hline \multicolumn{2}{|c|}{ Assumptions on exogenous variables } & \multicolumn{2}{|c|}{ Output sacrifice ratio } \\
\hline $\begin{array}{l}\text { Relative prices of food, } \\
\text { energy, and imports }\end{array}$ & $\begin{array}{c}\text { Effective } \\
\text { minimum wage }\end{array}$ & $\begin{array}{l}\text { Discounted } \\
\text { at } 0 \text { percent }\end{array}$ & $\begin{array}{l}\text { Discounted } \\
\text { at } 3 \text { percent }\end{array}$ \\
\hline No change & No change & 8.0 & 7.6 \\
\hline Actual change, 1981-84 & No change & 4.8 & 4.7 \\
\hline Actual change, 1981-84 & Actual change, 1981-84 & 3.9 & 3.9 \\
\hline $\begin{array}{l}\text { Actual change, } 1981-84 \text {, } \\
\text { followed by four-year } \\
\text { rebound }\end{array}$ & Actual change, 1981-84 & 8.5 & 7.5 \\
\hline
\end{tabular}

Source: Constrained version of equation in table 3, column 1 .

the model helped to speed up the disinflation. Because exchange rate changes have proved to be impossible to track in any model, that approach cannot be repeated here. Instead a simpler method is used to calculate the sacrifice ratio. First, in line 1 of table 6 , the reduced-form inflation equation (the constrained version of table 3 , column 1) is subjected to a "cold-turkey" permanent slowdown of excess nominal GNP growth of 5 percentage points, starting from an equilibrium situation in which inherited inflation is equal to excess nominal GNP growth, and supply-shift variables are all set equal to zero. The calculated sacrifice ratio, based on a forty-eight-quarter simulation, is 8.0 without discounting, compared with the analogous calculation of 8.4 in Gordon-King (table 5, line 4). ${ }^{19}$

To allow for the effects of food, energy, and nonfood, nonfuel import prices, I adopt the simple device of setting the values of these variables for the first four years of the twelve-year simulation at their actual values realized in 1981-84. This cuts the undiscounted sacrifice ratio from 8.0 to 4.8 , with a similar reduction in the sacrifice ratio discounted at 3 percent. When the actual decline in the effective minimum wage rate of 1981-84 is included, the sacrifice ratio declines further, from 4.8 to 3.9.

\section{EFFECTS OF A COLLAPSE IN THE DOLLAR}

Part of the beneficial effect on the sacrifice ratio of the lower relative prices of food, energy, and nonfood, nonfuel imports may be due to the post-1980 appreciation of the dollar and may be only temporary. To

19. The formula for the calculation is shown in Gordon and King, "Output Cost of Disinflation," p. 229. 
assess consequences of a possible dollar depreciation, the sacrifice ratio on line 4 is recalculated on the assumption that the average value of the food-energy effect and of the import price term for the second four years of the simulation is the negative of their average values during 1981-84. This returns the sacrifice ratio roughly to the values on line 1 . Those who believe that the dollar may depreciate not to its 1980 value but only part of the way can choose intermediate values of the sacrifice ratio, as they wish. ${ }^{20}$

An alternative estimate of the effect of a dollar depreciation can be calculated. Because the exchange rate does not appear directly in the reduced-form inflation equation, it is necessary to add equations that regress the food-energy effect and the import price term on their own lagged values, as well as current and lagged values of changes in the effective exchange rate. In these equations (not reported here to save space) the elasticity of the food-energy term to a permanent change in the exchange rate is -0.11 and of the import price term is -0.41 , with both of these sums of coefficients highly significant. A dynamic simulation can be carried out of a model consisting of the basic reduced-form inflation equation (table 3 , column 1 ), identity 23 , and the auxiliary equations for the food-energy effect and import prices.

Such simulations can be carried out using two alternative assumptions about aggregate demand. With excess nominal GNP treated as exogenous, the result is that a depreciation of the dollar over four years back to its average value of 1980:4 (an annual depreciation rate of 11 percent) would increase inflation by an average of 1.3 percent per annum for the first four years but not at all for the next four years. Because nominal GNP growth is held fixed, the additional inflation causes a corresponding reduction in the output ratio that holds down the inflationary impact of the depreciation. The alternative is to hold the log output ratio fixed at zero. In that case, the same path of depreciation creates additional inflation of 1.9 percent per annum in the first four years and a surprising 4.0 percent per annum in the next four years, with the acceleration due to the endogenous feeding through of the lagged inflation terms. What happens in this simulation is that excess nominal GNP growth must

20. Stanley Fischer has developed a comprehensive theoretical analysis of the relationship between exchange rate movements and the sacrifice ratio, taking account of the fact that part or all of the exchange rate appreciation during a disinflation may be temporary. See his "Real Balances, the Exchange Rate and Indexation: Real Variables in Disinflation," Working Paper 1497 (National Bureau of Economic Research, November 1984). 
accelerate permanently by 4.0 percentage points to maintain a fixed log output ratio of zero.

\section{Conclusion}

Is the description of the U.S. inflation process developed during the 1970s still intact in the mid-1980s? The findings in this paper support a theme of continuity, rather than change.

A series on the natural rate of unemployment and a corresponding series on the log ratio of actual to natural real GNP seem to remain valid. There has been no further upward drift of the natural unemployment rate above 6 percent. A corollary of this finding is that there is still modest room for expansion of real GNP at a faster rate than the 2.8 percent growth rate of natural real GNP (estimated in my 1984 paper). The output ratio in 1984:4 was -3.3 percent, implying that real GNP could grow at 4.4 percent annually for the two years 1985 and 1986 without raising actual output above the natural level.

Calculations with the basic reduced-form inflation equation suggest that the best policy to achieve a soft landing at the 6.0 percent natural unemployment rate would be to maintain excess nominal GNP growth at 5.0 percent in 1985 and 1986 , and at 4.0 percent thereafter. The corresponding values for actual nominal GNP growth are 7.8 percent in 1985 and 1986, and 6.8 percent thereafter. This allows inflation to be maintained permanently at 4.0 percent (in the absence of supply shocks) and the log output ratio to be maintained at zero after 1986.

The reduced-form inflation equation is derived from a simple model of labor demand and supply with slow wage adjustment. Although the model suggests that changes in indirect, payroll, and personal tax rates should influence wage and price changes, empirically there is no evidence of significant tax effects. Thus, at least in these data, there is no support for the notion that the Reagan tax cuts helped to cause a moderation of wage or price changes. These findings, however, may in part reflect the limitations of working with effective rather than statutory tax rates.

The government's only important "self-inflicted wound" was the increase in the minimum wage enacted during the Carter years. The erosion of the effective minimum wage during the last four years has made a modest contribution to disinflation.

There is only very weak evidence of "cost-push" in U.S. wage and 
price setting, in the sense of unidentified upward pressure on the inflation rate that cannot be linked to particular variables. Dummy shift variables are positive but insignificant for periods since 1972 .

Although the exchange rate of the dollar does not enter directly into our basic reduced-form inflation equation, it is possible to use that equation to assess the consequences of a hypothetical depreciation of the dollar. Auxiliary equations suggest that the food-energy effect and the relative price of nonfood, nonfuel imports respond highly positively to a dollar depreciation. If the dollar were to return over four years to its 1980 value, the inflation rate over the four-year period would be about 1.3 percent a year higher if nominal GNP growth were held fixed. Maintaining a fixed output ratio (and a fixed unemployment rate) in the face of such a dollar depreciation would require a significant acceleration of nominal GNP growth and would raise the inflation rate permanently by 4 percentage points.

APPENDIX A

\section{Description of Data}

THIS APPENDIX lists the data sources and, where applicable, the method of construction for each variable included in any of the regressions in the main body of the paper.

\section{Real GNP $(Q)$}

Real gross national product from national income and product accounts (NIPA), table 1.2.

Natural Real GNP $\left(Q^{*}\right)$

Geometric interpolation between the benchmark quarters 1953:4, 1957:3, 1960:1, 1970:3, 1974:2, and 1979:3. The growth rate for post1979 is assumed to be 2.8 percent, as derived in Gordon, "Unemployment and Potential Output."

Output Ratio $(\hat{Q})$

The ratio of real GNP to natural real GNP. Calculated as $100 * \ln \left(Q / Q^{*}\right)$. 


\section{Inflation $(p)$}

1947-58. Percentage rate of change in implicit GNP deflator (NIPA,table $7.1)$.

1959-84. Percentage rate of change in the fixed-weight GNP deflator (NIPA, table 7.2).

Change in Relative Food and Energy Prices

Calculated as the difference of the rate of change in the fixed-weight deflator for consumption (NIPA, table 7.2) and the rate of change in the fixed-weight deflator for consumption excluding food and energy (NIPA, table 7.2).

Change in Relative Import Prices $(f-p)$

1947-66. Calculated as the difference of the rate of change in the fixedweight deflator for imports (NIPA, table 7.2) and the rate of change in the GNP deflator described above.

1967-84. Calculated as the difference of the rate of change in the fixedweight deflator for nonfood, nonfuel merchandise imports (constructed by Wing T. Woo) and the rate of change in the GNP deflator.

Change in the Foreign Exchange Rate

The rate of change in the effective foreign exchange rate (International Monetary Fund, International Financial Statistics).

Relative Change in Consumer Prices $(c-p)$

The rate of change in the consumer price index (U.S. Bureau of Economic Analysis, Business Conditions Digest, series 320) minus the rate of change in the GNP deflator.

Effective Minimum Wage

The rate of change in the nominal minimum wage (Social Security Bulletin) minus the rate of change in average hourly earnings, private nonfarm payrolls (U.S. Bureau of Economic Analysis, Survey of Current Business).

Effective Payroll Tax $\left(T^{S}\right)^{1}$

The effective payroll tax rate is defined as the ratio of contributions for social insurance, defined as federal (NIPA, table 3.2) plus state and local (NIPA, table 3.3) contributions to social insurance, to private wages and salaries, defined as total wages and salaries (NIPA, table 1.11) less wages and salaries of government and government enterprises (NIPA, table 1.11).

1. This and the two following tax variables are entered in the form $100 * \ln \left(T_{t} / T_{t-1}\right)$, where $T=1 /(1-\tau)$, and $\tau$ is the effective tax rate defined above. 
Effective Personal Tax $\left(T^{P}\right)$

The effective personal tax rate is defined as the ratio of personal tax receipts, that is, federal (NIPA, table 3.2) plus state and local receipts (NIPA, table 3.3), to personal income (NIPA, table 2.1).

Effective Indirect Tax $\left(T^{I}\right)$

The effective indirect tax rate is calculated as the ratio of indirect business tax receipts, that is, federal (NIPA, table 3.2) plus state and local receipts (NIPA, table 3.3), to private gross national product. Private GNP is computed by subtracting government purchases of goods and services (NIPA, table 1.1) from gross national product (NIPA, table 1.1).

Excess Money Supply Growth $(\hat{m})$

The growth rate is the growth in the money supply minus the rate of growth of natural real GNP. The money supply is M1. From 1954 to 1958, M1 is the "old" M1 Series, from the Board of Governors of the Federal Reserve System, Federal Reserve Bulletin. From 1959 to 1984, it is the "new" M1 Series, from the Federal Reserve Bulletin.

Productivity Trend $\left(\theta^{*}\right)$

The trend productivity growth was calculated as the geometric rate of growth in nonfarm business output per hour between the benchmarks 1953:4, 1957:3, 1960:1, 1970:3, 1974:2, and 1979:3. The trend rate of productivity growth for post-1979:3 is assumed to be 1.01. (See Gordon, BPEA, 2:1984, for details.)

Productivity Deviation $\left(\theta-\theta^{*}\right)$

The rate of change in output per hour in the nonfarm business sector (Business Conditions Digest, series 358) less the trend rate of growth in productivity.

Excess Nominal GNP Change $(\hat{y})$

The rate of change in nominal GNP (NIPA, table 1.1) minus the rate of growth of natural real GNP (see above).

Civilian Unemployment Rate $(U)$

Business Conditions Digest, series 43.

Natural Unemployment Rate $\left(U^{*}\right)$

The natural unemployment rate calculated in Gordon, "Flexible Exchange Rates." The natural unemployment rate after 1980 is assumed to be 6 percent.

Velocity Change $(v)$

The rate of change of nominal GNP minus the rate of growth of the money supply. 


\section{APPENDIX B}

\section{Data Values, 1954-84}

Table B-1. Annual Averages of Dependent and Independent Variables, 1954-84

\begin{tabular}{|c|c|c|c|c|c|}
\hline Year & $\begin{array}{c}\text { Real GNP } \\
\text { (billions of } \\
1972 \\
\text { dollars) }\end{array}$ & $\begin{array}{c}\text { Natural } \\
\text { real GNP } \\
\text { (billions of } \\
1972 \\
\text { dollars) }\end{array}$ & $\begin{array}{c}\text { Output } \\
\text { ratio } \\
\text { (percent) }\end{array}$ & $\begin{array}{l}\text { Unemploy- } \\
\text { ment rate } \\
\text { (percent) }\end{array}$ & $\begin{array}{c}\text { Natural un- } \\
\text { employment } \\
\text { rate } \\
\text { (percent) }\end{array}$ \\
\hline 1954 & 615.6 & 629.7 & -2.2 & 5.6 & 5.1 \\
\hline 1955 & 657.4 & 647.9 & 1.5 & 4.4 & 5.1 \\
\hline 1956 & 671.7 & 666.5 & 0.8 & 4.1 & 5.1 \\
\hline 1957 & 683.6 & 685.8 & -0.3 & 4.3 & 5.1 \\
\hline 1958 & 681.9 & 706.2 & -3.6 & 6.8 & 5.0 \\
\hline 1959 & 721.7 & 727.4 & -0.8 & 5.5 & 5.1 \\
\hline 1960 & 737.0 & 751.4 & -2.0 & 5.5 & 5.1 \\
\hline 1961 & 756.5 & 779.7 & -3.0 & 6.7 & 5.2 \\
\hline 1962 & 800.3 & 809.1 & -1.1 & 5.6 & 5.3 \\
\hline 1963 & 832.2 & 839.6 & -0.9 & 5.6 & 5.4 \\
\hline 1964 & 876.0 & 871.2 & 0.5 & 5.2 & 5.5 \\
\hline 1965 & 929.0 & 904.1 & 2.8 & 4.5 & 5.6 \\
\hline 1966 & 984.6 & 938.1 & 5.0 & 3.8 & 5.6 \\
\hline 1967 & 1011.4 & 973.5 & 3.9 & 3.8 & 5.6 \\
\hline 1968 & 1058.1 & 1010.2 & 4.7 & 3.6 & 5.6 \\
\hline 1969 & 1087.6 & 1048.3 & 3.7 & 3.5 & 5.6 \\
\hline 1970 & 1085.6 & 1087.8 & -0.2 & 5.0 & 5.6 \\
\hline 1971 & 1122.4 & 1128.5 & -0.5 & 6.0 & 5.8 \\
\hline 1972 & 1185.9 & 1170.7 & 1.3 & 5.6 & 5.8 \\
\hline 1973 & 1254.3 & 1214.5 & 3.3 & 4.9 & 5.8 \\
\hline 1974 & 1246.3 & 1258.8 & -1.0 & 5.6 & 5.9 \\
\hline 1975 & 1231.7 & 1300.5 & -5.3 & 8.5 & 6.0 \\
\hline 1976 & 1298.2 & 1343.2 & -3.3 & 7.7 & 5.9 \\
\hline 1977 & 1369.7 & 1387.3 & -1.3 & 7.0 & 6.0 \\
\hline 1978 & 1438.6 & 1432.8 & 0.4 & 6.0 & 5.9 \\
\hline 1979 & 1479.4 & 1479.4 & 0.0 & 5.8 & 5.9 \\
\hline 1980 & 1475.0 & 1522.7 & -3.1 & 7.1 & 5.9 \\
\hline 1981 & 1512.2 & 1565.9 & -3.1 & 7.6 & 6.0 \\
\hline 1982 & 1480.0 & 1610.4 & -8.2 & 9.7 & 6.0 \\
\hline 1983 & 1534.7 & 1656.1 & -7.3 & 9.6 & 6.0 \\
\hline 1984 & 1639.9 & 1703.1 & -3.7 & 7.5 & 6.0 \\
\hline
\end{tabular}


Table B-2. Dependent and Independent Variables, Percentage Change at Annual Rates, 1954-84

Four-quarter change spanning listed year

\begin{tabular}{|c|c|c|c|c|c|c|}
\hline Year & Inflation & $\begin{array}{l}\text { Relative } \\
\text { import } \\
\text { prices }\end{array}$ & $\begin{array}{l}\text { Relative } \\
\text { food } \\
\text { and } \\
\text { energy } \\
\text { effect }\end{array}$ & $\begin{array}{l}\text { Effective } \\
\text { minimum } \\
\text { wage }\end{array}$ & $\begin{array}{l}\text { Produc- } \\
\text { tivity } \\
\text { trend }\end{array}$ & $\begin{array}{c}\text { Produc- } \\
\text { tivity } \\
\text { deviation }\end{array}$ \\
\hline 1954 & 1.86 & $\ldots$ & $\ldots$ & -2.36 & 1.95 & 0.70 \\
\hline 1955 & 2.64 & $\ldots$ & $\ldots$ & -4.01 & 1.95 & 0.63 \\
\hline 1956 & 3.68 & $\ldots$ & $\cdots$ & 23.51 & 1.95 & -1.16 \\
\hline 1957 & 2.63 & $\ldots$ & $\ldots$ & 4.37 & 2.06 & -0.43 \\
\hline 1958 & 1.67 & $\ldots$ & $\ldots$ & -3.03 & 2.78 & 1.33 \\
\hline 1959 & 1.90 & 0.71 & -0.36 & -3.53 & 2.78 & -2.04 \\
\hline 1960 & 1.55 & -2.08 & 0.27 & -3.13 & 2.43 & -1.72 \\
\hline 1961 & 0.70 & -1.10 & -0.27 & 11.40 & 2.35 & 2.94 \\
\hline 1962 & 1.38 & -3.68 & 0.13 & -3.58 & 2.35 & 0.53 \\
\hline 1963 & 1.09 & 1.73 & -0.13 & 5.96 & 2.35 & 0.45 \\
\hline 1964 & 1.22 & -0.03 & 0.13 & 3.76 & 2.35 & 1.14 \\
\hline 1965 & 1.86 & 0.09 & 0.51 & -4.51 & 2.35 & 1.14 \\
\hline 1966 & 3.37 & -1.33 & 0.24 & -4.31 & 2.35 & -1.14 \\
\hline 1967 & 3.01 & -3.54 & -0.50 & 6.83 & 2.35 & 0.15 \\
\hline 1968 & 4.35 & -1.96 & -0.12 & 6.51 & 2.35 & 0.21 \\
\hline 1969 & 5.19 & -0.02 & 0.22 & -6.53 & 2.35 & -3.50 \\
\hline 1970 & 4.72 & 1.96 & -0.22 & -5.40 & 2.14 & -1.10 \\
\hline 1971 & 4.40 & 0.07 & -0.10 & -6.47 & 1.49 & 2.23 \\
\hline 1972 & 4.12 & 4.66 & 0.40 & -6.69 & 1.49 & 3.16 \\
\hline 1973 & 6.94 & 13.71 & 3.15 & -6.87 & 1.49 & -1.38 \\
\hline 1974 & 10.45 & 15.33 & 1.36 & 14.13 & 1.29 & -3.96 \\
\hline 1975 & 7.10 & -7.46 & 0.51 & -1.77 & 1.09 & 2.63 \\
\hline 1976 & 5.11 & -0.91 & -1.41 & 2.26 & 1.09 & 1.08 \\
\hline 1977 & 6.52 & 3.00 & -0.02 & -7.89 & 1.09 & 1.43 \\
\hline 1978 & 8.54 & 2.81 & 0.82 & 5.76 & 1.09 & -0.79 \\
\hline 1979 & 8.85 & 5.99 & 2.62 & 1.59 & 1.07 & -3.18 \\
\hline 1980 & 9.66 & 2.78 & 1.11 & -0.35 & 1.01 & -0.81 \\
\hline 1981 & 8.52 & -9.82 & -0.51 & -7.40 & 1.01 & 0.10 \\
\hline 1982 & 5.06 & -8.46 & -1.14 & -4.73 & 1.01 & -0.11 \\
\hline 1983 & 3.90 & -4.83 & -0.99 & -4.64 & 1.01 & 2.50 \\
\hline 1984 & 4.09 & -5.14 & -0.63 & -3.22 & 1.01 & 1.17 \\
\hline
\end{tabular}


Table B-3. Dependent and Independent Variables, Percentage Change at Annual Rates, 1954-84

Four-quarter change spanning listed years

\begin{tabular}{|c|c|c|c|c|c|}
\hline Year & $\begin{array}{c}\text { Effective } \\
\text { payroll } \\
\text { tax }\end{array}$ & $\begin{array}{c}\text { Effective } \\
\text { indirect } \\
\text { tax }\end{array}$ & $\begin{array}{l}\text { Effective } \\
\text { personal } \\
\text { tax }\end{array}$ & $\begin{array}{l}\text { Relative } \\
\text { consumer } \\
\text { prices }\end{array}$ & $\begin{array}{c}\text { Foreign } \\
\text { exchange } \\
\text { rate }\end{array}$ \\
\hline 1954 & 0.21 & -0.19 & -0.30 & -2.48 & $\ldots$ \\
\hline 1955 & 0.06 & -0.01 & 0.12 & -2.28 & $\ldots$ \\
\hline 1956 & 0.10 & 0.14 & 0.12 & -1.10 & $\ldots$ \\
\hline 1957 & 0.19 & 0.04 & -0.02 & 0.35 & $\ldots$ \\
\hline 1958 & 0.02 & 0.07 & -0.09 & 0.19 & $\ldots$ \\
\hline 1959 & 0.21 & 0.01 & 0.15 & -0.41 & $\ldots$ \\
\hline 1960 & 0.30 & 0.18 & 0.14 & -0.09 & $\ldots$ \\
\hline 1961 & 0.03 & 0.00 & -0.06 & -0.02 & 1.76 \\
\hline 1962 & 0.13 & 0.02 & 0.20 & -0.06 & 0.60 \\
\hline 1963 & 0.20 & -0.01 & -0.08 & 0.22 & 0.25 \\
\hline 1964 & -0.08 & 0.04 & -0.30 & 0.08 & -0.14 \\
\hline 1965 & -0.08 & -0.15 & -0.00 & -0.17 & 0.11 \\
\hline 1966 & 0.56 & -0.03 & 0.37 & 0.14 & 0.25 \\
\hline 1967 & 0.18 & 0.12 & 0.04 & -0.21 & 0.66 \\
\hline 1968 & -0.02 & 0.08 & 0.53 & 0.28 & 0.66 \\
\hline 1969 & 0.20 & 0.04 & -0.01 & 0.40 & 0.25 \\
\hline 1970 & 0.07 & 0.13 & -0.34 & 0.83 & -1.50 \\
\hline 1971 & 0.15 & -0.01 & -0.03 & -1.00 & -5.16 \\
\hline 1972 & 0.13 & -0.15 & 0.27 & -0.75 & -4.19 \\
\hline 1973 & 0.55 & -0.18 & -0.12 & 1.16 & -9.57 \\
\hline 1974 & 0.22 & 0.06 & 0.16 & 0.94 & 3.20 \\
\hline 1975 & 0.08 & 0.00 & -0.30 & -0.03 & 2.21 \\
\hline 1976 & 0.10 & -0.07 & 0.27 & -0.21 & 1.93 \\
\hline 1977 & 0.01 & -0.09 & 0.02 & -0.11 & -2.74 \\
\hline 1978 & 0.08 & -0.26 & 0.19 & -0.01 & -11.16 \\
\hline 1979 & 0.14 & -0.04 & 0.12 & 3.18 & 2.62 \\
\hline 1980 & -0.00 & 0.17 & 0.02 & 2.16 & 0.29 \\
\hline 1981 & 0.33 & 0.08 & 0.03 & 0.62 & 12.94 \\
\hline 1982 & 0.14 & 0.06 & -0.18 & -0.63 & 13.83 \\
\hline 1983 & 0.11 & -0.08 & -0.25 & -0.64 & 3.80 \\
\hline 1984 & 0.20 & -0.01 & 0.05 & -0.08 & 10.08 \\
\hline
\end{tabular}




\section{Comments and Discussion}

Robert E. Hall: Robert Gordon's paper starts with a detailed exposition of a reasonably standard view of the inflation process. Wage inflation is driven by excess demand and inertia. The price level is a markup over wage and other costs. As Gordon has shown in a number of recent papers, the standard view has held up well in the 1980s. A dramatic slowdown in inflation was brought about by slack labor markets, stable food and energy prices, and cheaper imports. The only threat of rising inflation visible today is rising import prices in the event that the overvalued dollar returns to a more normal level.

The only part of the theory called into question by recent experience is markup pricing, which seems to fail in the case of imports. U.S. prices have fallen less than predicted by a simple model in which the U.S. price of imported goods is a simple markup over the foreign price restated in dollars at the prevailing exchange rate. The U.S. pricing of imports seems to be quite sensitive to conditions in U.S. markets, less sensitive to costs of production. That makes good economic sense, but it goes against the spirit of the markup hypothesis, in which costs are the predominant determinant of price. But I do not want to suggest that standard competitive theory would do a good job of explaining the U.S. price level in recent years either.

The heart of Gordon's paper is a set of regressions of the rate of price inflation on various determinants. It is a good idea to ask what, in principle, can be learned from these regressions. In general, a regression of one endogenous variable on another tells nothing about the structural relations of the two variables. Gordon's procedure may avoid the standard problem of simultaneity by invoking lags. If excess demand operates with a lag, then there is a reasonable chance that the type of regression shown in Gordon's table 2 will reveal something about the 
structural Phillips curve. But further obstacles to estimation of the true dynamic relation exist.

If the Phillips curve has a serially correlated disturbance, Gordon's regressions, with their lagged inflation components, will not reveal the true structural relationship. Even the sums of coefficients that he stresses will be biased in certain cases. If inflation shocks are persistent, the sums of coefficients on excess demand and similar variables will be biased downward. On the other hand, if there are nonpermanent shocks in the price level, the bias will go in the opposite direction. Unfortunately, there is no way to determine the serial correlation properties in the disturbances in Gordon's framework. Because of the lagged inflation terms, the residuals in his equations are invariably serially uncorrelated, no matter what the properties of the original shocks are.

Fortunately, two properties of the equation are immune to this bias: estimates of the sum of coefficients on lagged inflation and estimates of the natural unemployment rate. I suspect that Gordon's finding that the natural rate has stabilized around 6 percent is robust.

One of the major topics of this meeting has been the likely effect of a reversal of the ascent of the dollar. Gordon's investigation suggests that four successive years of 11 percent depreciation would increase inflation by 2 extra percentage points a year for four years, then by 4 extra points a year thereafter. This calculation assumes that real GNP maintains the same path it would have followed absent the depreciation. If I understand his work correctly, about three-quarters of the effect of depreciation operates through food and energy and only one-quarter through other imports. It is true that the elasticity of the price of other imports with respect to the exchange rate is 0.41 , as against 0.11 for food and energy prices. But food and energy prices have a remarkable coefficient of about 0.55 in the inflation equations of table 2, compared with only about 0.05 for other imports. Statistically speaking, Gordon cannot rule out the possibility that other imports have no role in U.S. domestic inflation. A great deal depends on the reliability of the proposition that each 10 percent depreciation of the dollar raises the dollar world oil price and other food and energy prices by 1 percent.

\section{General Discussion}

Benjamin Friedman observed that the disinflation of the past several years corresponds closely to the evidence on the sacrifice ratio summa- 
rized by Arthur Okun during the 1970s only when unemployment is used to measure the cost of disinflation, not when cost is measured by output loss, as in Robert Gordon's assessment. Okun indicated that a range of 2 to 6 point years of unemployment, with a median estimate of 3 point years, would be required to reduce inflation by 1 percentage point. The experience of recent years shows a ratio of about 2.5 , which is near Okun's median. However, when an Okun's law coefficient of 3 is used to convert unemployment points to output gaps, Okun's range in terms of lost output becomes 6 to 18 percent. It is only because the Okun's law coefficient in recent years has apparently been well below 3 that the sacrifice ratio in terms of output, as in Gordon's table 6, appears near or below the bottom of Okun's range.

Several Panel members discussed how to model exchange rate effects in an inflation model such as Gordon's. Stephen Marris argued that a stable lag on import prices is inadequate for a number of reasons. When exchange rates move, both importers and exporters will have to choose among altering profit margins, volumes, and prices. The time period over which margins or prices are varied will be different and will depend on the level of the exchange rate relative to its history over a period of years. He reasoned that when the dollar started rising in 1980, it was undervalued, and that, initially, the primary effects of appreciation were on profit margins, both here and abroad. William Nordhaus added that a markup view of pricing may be appropriate for the domestic market but that it is inappropriate for export markets. In foreign markets, firms are much more likely to be marginalists, particularly when they are a small part of the market. By contrast, when firms have considerable market power in a foreign country, they are more likely to absorb exchange rate movements through profit margin variations.

Christopher Sims found it hard to interpret Gordon's price equation, because it included contemporaneous variables set in auction markets, such as food and exchange-rate sensitive prices. Because such markets absorb all current economic information, innovations in such variables have no straightforward interpretation and can distort the estimated effects of other variables in the equation. In particular, auction-market variables will absorb some of the contemporaneous disturbances in the labor market, thus distorting the estimated effects of labor market innovations. 